\title{
The Double Bind of Interculturality and the Implications for Education
}

\author{
Robert Aman
}

\section{Linköping University Post Print}

\section{Tweet}

N.B.: When citing this work, cite the original article.

This is an electronic version of an article published in:

Robert Aman, The Double Bind of Interculturality and the Implications for Education, 2015, Journal of Intercultural Studies, 36(2), 149-165.

Journal of Intercultural Studies is available online at informaworldTM:

http://dx.doi.org/10.1080/07256868.2015.1008431

Copyright: Taylor \& Francis (Routledge): SSH Titles http://www.routledge.com/

Postprint available at: Linköping University Electronic Press

http://urn.kb.se/resolve?urn=urn:nbn:se:liu:diva-114855 


\title{
The Double Bind of Interculturality, and the Implications for Education
}

\author{
ROBERT AMAN
}

\section{Abstract}

This essay explores the ways in which boundaries of estrangement are produced in the academic literature assigned for courses on interculturality. As the existence of interculturality is dependent on the ascription of content to culture - since the notion, by definition, always involves more than one singular culture - this essay seeks to provide an answer to the question of what this literature, implicitly or otherwise, defines in terms of sameness vis-à-vis otherness, and thereby to chart the conditions for becoming intercultural. This question is especially important because the self in interculturality has to be, in principle, generalizable: it should signify a position available for occupation by anybody with proper training in this approach. Starting from the assumption that different experiences, languages and identities, already intersect with, and are contaminated by, one another under the name of culture, and are therefore already intercultural before being subjected to study under the auspices of 'interculturality' as an educational topic, the essay goes on to problematize the way in which interculturality tends to construe sameness and difference along national lines and does little to cater for multiple, as opposed to national, or other unified, identities.

Keywords: interculturality; otherness; education; multiculturalism; diversity; border.

Towards the end of Amitav Ghosh's novel, The Shadow Lines (1988: 185-186), the narrator's failing grandmother thoughtfully poses a question that has puzzled her: will she see the border from the plane? In the form of a family chronicle, Ghosh depicts the crossing and recrossing of geopolitical borders. Not only the border that joins and divides Calcutta and London - East and West - but also the border between Calcutta and Dhaka. Residing in Calcutta, the old woman is now preparing to return to Dhaka her place of birth - which she left many years ago following the partition of India. Same city, different nations: Dhaka was then the capital of East Pakistan, now Bangladesh. In response to her question about the visibility of the redrawn border from the air, her son laughingly informs her that there will be no resemblance at all to the maps, familiar to all of us, from classroom walls, with different colours on either side of a distinctive bold red line. 'But surely,' she persists, 'there's something - trenches perhaps, or soldiers, or guns pointing at each other, or even just barren strips of land. Don't they call it no man's land?' Again her son chuckles: 'No you won't be able to see anything except clouds.' Still slightly bewildered, the old woman replies: 'But if there aren't any trenches or anything, how are people to know? I mean, where's the difference then? [...] What was it all for then - Partition and all the killing and everything - if there isn't something in between?'

The significant issue for this essay is precisely this absence of in between: what Ghosh's story illustrates is the fact that both sameness and difference lack essence; what was the same today can be other tomorrow. Nationhood, like borders, is merely an artificial construct - never physical, never embodied, never pure (cf. Anderson 1982). Yet borders are necessary to split space into domestic and alien territory; to distinguish between sameness and otherness, domestic and foreign, us and them. History offers 
countless examples: Greeks separated themselves from those they deemed Barbarians based on language; a European identity was dialectically constituted through the mechanisms of colonial racism; nation-state building made claims to particularity through the representation of a population as culturally, linguistically and theologically homogenous in relation to outsiders. Consequently, we find out who we are by a kind of 'ostensive self-definition by negation', establishing a border between self and other by articulating who we are not; the Other provides the mirror in which we perceive ourselves (White 1972: 5).

Borders that separate sameness from difference, Homi Bhabha (1994) asserts, are sustained in the irrefutable pedagogy of the nation that imbues the identity of its population with cultural signifiers such as shared history, common language and collective values, with the objective of authenticating the inside of the national space as against the outside while, at the same time, negating the internal diversity of the people. From this point of view, pedagogy is both a poison and an antidote, a problem and yet a solution: education, it is argued, serves to denationalize both students and scholars by making them broad-minded and open to alternative views and lifestyles (Hughes 2009). And in the field of education, nowhere is the question of the understanding of and identification with the traditions of the 'Other' more apparent than in writings on interculturality. Having become a commonplace in educational rhetoric over the last decade, interculturality is seen as a tool for bridging cultural differences and breaking out of the nihilistic tendencies of multiculturalism's enclosure of subjects within partitioned cultures (Meer \& Modood 2011). 'Intercultural Education provides all learners with cultural knowledge, attitudes and skills', proclaims UNESCO (2006: 37), 'to contribute to respect, understanding and solidarity among individuals, ethnic, social, cultural and religious groups and nations.' Although 'culture' is merely, as Gayatri Chakravorty Spivak reiterates (1992: 775), 'a word like value in Marx, simple and contentless, immediately codable as ground of difference', the existence of interculturality is dependent on the ascription of content to culture since the notion, by definition, always involves more than one singular culture. Practically speaking, this entails contemplating how otherness is defined and how engagement with otherness leaves intact or challenges the very differences that categorize the Other as other.

By means of an examination of academic literature assigned for courses on interculturality, I set out to explore how boundaries of estrangement are produced in these texts by focusing on the type of subject that is used as a basis for analysis in Western scholarly writing on interculturality: more precisely, who slips into the position of agent in interculturality? This essay seeks to provide an answer to the question of what this literature, implicitly or otherwise, defines in terms of sameness $v i s-\grave{a}$-vis otherness, and thereby to chart the conditions, the rules of engagement, for becoming intercultural. Given that interculturality - in stark contrast to multiculturalism - possesses a compellingly positive meaning in liberal democracies based on the possibility of, and desire for, mutual empathy in interacting across differences (cf. Meer \& Modood 2011), my approach is informed not only by the lack of critical interventions on the subject (cf. Lentin 2005) but also by the fact that Europe's relation to its Others is still burdened by colonialism (Spivak 1985). In other words, I begin from the assumption that a unity - an 'us' - is never given but is assigned by alterity, that there was no 'race' before political science, no ethnicity before colonial anthropology and, as illustrated by the grandmother in Ghosh's novel, that the nation and its arbitrary borders - precedes the 'people'.

Before embarking on this task, however, I need to provide some background to set the stage. In what follows, I will begin by contextualising interculturality in order 
to resolve some conceptual confusion before elaborating on the theoretical itinerary that guides my analysis, in which a distinction is made between interculturality as an ontological category and as a set of theories. In the second and major part of the essay, I develop a critique of a particular understanding of the concept of 'culture' in 'interculturality' as positing something that others bring to the nation, which turns interculturality into an educational strategy for accepting and integrating the Other. I then examine the way in which such a model also, in an apparently contradictory manoeuvre, reifies difference as something inscribed in the body or culture of the Other.

\section{Multiculturalism contra Interculturality}

The far-reaching spread of interculturality opens up several avenues for discussing the ways in which the notion is being interpreted, translated, and deployed. Rather than seeking to provide an all-encompassing overview of interculturality, this section will concentrate on major themes that are discernible in the literature on this subject. For the same reason, possible connections between, or the potential interchangeability of, interculturality and other concepts used to bridge the culturally specific, such as 'cosmopolitanism' (Appiah 2006), 'transnationalism' (Smith \& Guarnizo 1998), or even 'World Literature' (Damrosch 2003), will not be brought up as this would require an act of translation between concepts that are all just as contested and varyingly coherent in themselves as interculturality.

What first strikes any reader engaging with the body of literature on interculturality is its employment alongside multiculturalism. Arguably, the particular appeal of interculturality in the many domains in which it has gained momentum - from policy writings to university curricula and academic scholarship - becomes more comprehensible when it is situated within a wider framework, in which the growing lack of enthusiasm for multiculturalism plays a part in the attractiveness of interculturality. For instance, Germany's Angela Merkel, the United Kingdom's David Cameron and France's Nicolas Sarkozy all recently labelled multiculturalism an 'utter failure' (Weaver 2010). The roots of this disenchantment with multiculturalism can be traced to the conceptual confusion surrounding it. On the one hand, multiculturalism often serves as a catch-all for a multitude of minority histories irrespective of gender, sexuality or ethnicity (Kymlicka 2003). Thus, it may serve as a descriptive label for cultural pluralism or diversity in any given society and for the ways in which the state supports and recognizes that pluralism; it also refers to educational issues and reformations of curricula and to policies and strategies adopted to govern and manage diversity. Finally, multiculturalism is said to refer to the normative justification of those very policies and strategies (Murphy 2005).

On the other hand, interpretations of multiculturalism vary greatly between the socio-political contexts in which the term is deployed: in North America, for instance, multiculturalism encompasses societal attempts to combat the historical exclusion of a wide variety of groups all marked by difference, from the disabled to indigenous populations, from sexual orientations to speakers of languages other than English. In Western Europe, by contrast, multiculturalism is considered to have a more limited meaning, usually encouraging hospitable attitudes towards new generations of immigrants (Meer \& Modood 2011). Different in meaning, united in consequences: part of the critique that the concept generates is that each of these variations fosters its own simplifications, generalizations or collective amnesias (McDonald 2011). For instance, any distinctions between the Algerian in Paris, the Northern Irish in London and the Sámi in Stockholm are blurred, which in turn does not take into account 
disparities within each grouping. In summation, the critique directed towards multiculturalism is that it has become an empty signifier, a conceptual void, onto which 'a range of groups projects their fears and hopes' (Bhabha, 1994: 31).

It seems fair to say that the complexity and confusion surrounding multiculturalism has played a part in its retreat; and this is of course also part of the reason why it has largely been replaced by interculturality in government policies and public debates that address different forms of pluralism both on a supranational level (European Union, UNESCO, Council of Europe) and within various national polities in Europe (Leeman 2003). Although multiculturalism remains in use, the impetus for the lexical change from one prefix (multi) to another (inter) derives, as some advocates of interculturality have suggested, from the fact that multiculturalism tends to reify and preserve cultural identities, while interculturality acknowledges that cultures are endlessly evolving in a society, with the potential to be exchanged and modified (cf. Gundara \& Portera 2008). Consequently, wherever interculturality is primarily used it is employed distinctively from multiculturalism: the latter is seen to be a descriptive term for the factual co-existence of people of diverse cultures in a given space, whereas the former is said to characterize actual interaction between people once impediments to relations have been removed (Gundara 2000). Hence the positive connotations of the notion of interculturality are at war with the negative associations of the word multiculturalism. Or, as argued by academic commentators, while multiculturalism both begins and ends by making a diagnosis, intercultural education offers a cure: 'learning to live in an ethnically and culturally diverse society' (Leeman, 2003: 31).

Without denying the existence of different interpretations and understandings of interculturality, however, several scholars have pointed out a common problem: interculturality and intercultural education, they argue, suffers from 'theoretical weakness' (Coulby 2006: 254) and the overwhelming majority of work on intercultural education tends to accentuate rather than undermine existing political and social hierarchies (Gorski 2008). In accordance with this, other academic commentators have concluded that researchers interested in this field implicitly assume the value of interculturality, in which they are often themselves engaged as activists or practitioners, and are therefore reluctant to propose any critiques of the concept in attempts to justify, elucidate and legitimize its ubiquity (Chaudhuri 2002).

\section{Interculturality and the Culturalization of Otherness}

For all the seductive possibilities it offers in term of bridging cultural specificities, it must be remembered that interculturality, relying on its root-word, 'culture' and recognizing it as a force in the world, with the added prefix of 'inter' suggesting movement across borders of various kinds, is a perspective that demands, as does any other theory, assimilation to its own point of view. Given the significance of historical factors in forming ethnic, racial and cultural relations, what must be taken into consideration are the structural, as well as the wider social, political and economicforces at work in all cultural relations.

To speak of a hierarchical approach to culture, however, is not to dispute the existence of different conceptions of culture; or that there are prevalent strains in contemporary intellectual debates that derive from either anthropology, where 'culture' generally refers to 'ways of life' inclusive of common beliefs, attitudes, and behaviours basic to a group of human beings, or from literature, music and art, where 'culture' is frequently associated with the sum of achievements related to what are perceived as refined features of 'civilized life' (Chow 1998). Rather, what I am questioning here is 
the presumption that the movement of history is always a progression from one or another unified past to a more diverse and pluralistic future (McDonald 2011).

It is necessary to emphasize that such scepticism should not be confused with ethnocultural arguments for the coherence and homogeneity of national cultures. Quite the opposite: what I want to suggest is that all cultures, including dominant ones, are less unified and more blended than is often believed to be the case or than the governing ideology of a particular moment may presuppose. Against this background, it might prove tricky, then, to distinguish between self and Other by way of culture. Akin to the arbitrary nature of cultural relations, this point can be concretized by drawing attention to the complex issue of official languages. Although states legitimize themselves by designating certain languages as official ones, it is impossible, for someone standing at the border, to say exactly when and where Portuguese begins and Spanish stops, where Norwegian starts and Swedish ends, especially considering that languages in themselves are products of flows and encounters that leave their mark on vocabulary, syntax and proverbs. 'What is French but bad Latin?', Marcel Proust famously asked in In Search of Lost Time. ${ }^{\mathrm{i}}$

If, as Abdelkébir Khatibi (1993: 10) has suggested, nations tend to mask the fact that they are in themselves 'a plurality, a mosaic of cultures, if not a plurality of languages and genealogies', others have gone to great lengths to emphasize the sheer hybridity of all cultures and national identities. Edward Said writes (1994: 261): 'The history of all cultures is the history of cultural borrowing'; and Salman Rushdie adds (1991: 67) 'One of the most absurd aspects of this quest for national authenticity is that [...] it is completely fallacious to suppose that there is such a thing as a pure, unalloyed tradition from which to draw.' Although I acknowledge that there are powerful forces eager to deny or resist this, a trait we all - both 'us' and 'them', same and Other - share, one might say, is the fact of already being intercultural before making any commitment to the paradigm bearing this name.

Inspired by the Derridean distinction - only graspable in writing - between his invented term différance and différence, I will henceforth separate interculturality from interculturality to guide my analysis. Although lexically identical, interculturality (without italics) is not interculturality (with italics). Splitting the word into two reveals its fractured signification as the former indicates that different experiences, languages and identities under the name of culture already intersect with, and are contaminated by, one another, and are therefore already intercultural before being subjected to study under the auspices of interculturality as an educational topic; the latter denotes the contemporary set of theories connected to intercultural education, which invokes plurality as a condition for its existence, elevated for its own sake, with the attendant risk of (re)writing cultural divides into being through its demand for alterity.

What we will see in this essay is that there is a pedagogy of interculturality that sees itself as an educational strategy that can eradicate the borders built up between us, since cultures neatly hived off from each other seem no longer to be a serious option, oriented as we all are towards an Other and others. Here, however, we are also faced with the risk of a double bind since the pedagogical aspect of interculturality, to a great extent, is relient on the idea that difference is always-already in existence, in the process of which interculturality risks overwriting interculturality, replacing it with ethnicity, culture or race; running counter to the idea that 'an identity is never given, received or attained' (Derrida 1998a: 28). 
In view of the growing impact of interculturality as a strategy for dealing with otherness in educational debates (Jones 1999), and the impact of policies implemented by supranational bodies which is, at least in part, responsible for the rapid growth of the discipline in Europe (cf. Dewey 2008), I have surveyed literature lists assigned for courses on interculturality and have selected three texts that are not only in frequent circulation but also heavily cited. ${ }^{\text {ii }}$ These texts are to be regarded as representative examples of a broader discourse on interculturality in the West: I interrogate the workings of the language of intercultural education as marked by 'différance' in the simultaneous act of writing self and other, with specific attention to the persistent risk of presenting interculturality as a double bind. This question is especially important because the self in interculturality has to be, in principle, generalizable; it should signify a position available for occupation by anybody who is properly attuned to this way of thinking. Consequently, my analysis focuses on identifying manifestations of difference produced in these texts through the coding of culture as an explicit or implicit norm for sameness.

\section{Changing Times, Multicultural Times}

All the texts included here echo the arguments previously put forward by the EU and UNESCO for the importance of interculturality; emphasising an appreciation for diversity and the desire to facilitate dialogue. Interculturality is necessary 'in a changing society', argues Intercultural Pedagogy in Theory and Practice, because it offers guidance on how to act and live in a 'multicultural, multiethnic, global and intercultural' context (Lahdenperä 2004: 14). And Developing Intercultural Awareness goes so far as to assert that ' $\mathrm{t}$ ] here is, in the last years of the twentieth century, no more noble calling than to help the people of the world live together in peace and understanding with a fully developed spirit of inquiry about other cultures and other ways' (Kohls \& Knight 1994: ix).

Consequently, it is our differences - ethnic and/or cultural - that require us to learn how to live with diversity, and interculturality is to be regarded as a dispenser of such an educational model. Placing 'intercultural' alongside 'multicultural', the term more commonly used in policy texts, hints, on the one hand, at the existence of interculturality before interculturality, implying the heterogeneity and contamination of cultural identities which precedes the educational theories sharing the same name. On the other hand, this reasoning is blurred when read against the above statement on the transformation of society as a reason for the urgent need for interculturality; it is then a requirement tied to temporality which simultaneously constructs the binaries of past and present, sparing the former from what haunts the latter in terms of intensified proximity between people of different cultural backgrounds. It should be remembered that culture, ethnicity, or identity for that matter, are not words with fixed significations, but temporary products spreading over registers of complex variety and contextual specificity. To be more concrete, culture and identity are abstractions elevated from a flow of encounters, confrontations and crises - hence, interculturality before interculturality (Jonsson 1993). The timelessness of interculturality, however, instantly raises the question of the specific developments that temporally situated interculturality as a 'noble calling' of the twentieth century; the precise motives for the promotion of this educational strategy for the here and now. The answer, as one of the texts explains, can be traced to the impact of globalization. 
with separate ethnic and cultural backgrounds. [...] The teachers in these new multicultural learning milieus are today faced with a new situation. They must acquire a new way to relate to the new reality (Borgström 2004: 33).

What is particularly significant here is the causal relation between globalization and multiculturalism: the passage from local to global, but also from homogenous to heterogeneous, assures the transition from monocultural to multicultural. 'It is no longer merely about Sweden in the world', another text goes on to argue, 'but also about the world in Sweden as our country has become a multicultural society' (Lahdenperä 2004: 11). Without dismissing the changed compositions of several Western European societies in recent decades in the wake of population movement due to war, decolonization and economic migration, to explain the presence of pupils with 'separate ethnic and cultural backgrounds' is to suggest that globalization moves people into somebody else's previously homogenous back yard. Another way to put the point would be that globalization seemingly offers ambiguous permission for cultural and/or ethnic difference. If the reasoning above is adhered to, otherness becomes something that is inscribed into the body of the Other, 'they' carry it with 'them', as it is 'their' sheer presence that generates cultural diversity.

Yet, here, the language of interculturality presents an inbuilt amnesia: the modern nation emerges, from the mid-nineteenth century on, during one of the most sustained periods of mass immigration in the West, and alongside colonial expansion in the East (Bhabha 1994). In other words, the question to which interculturality sets out to be the prescribed answer carries historical traces: how shall 'we' accommodate the Other within 'our' borders? The newness of the answer to a question that colonial Europe asked itself long ago disavows interculturality in the name of interculturality - the answer refuses the narrative of overlapping and intertwined pasts, making the absence of interculturality a rhetorical strategy for the presence of interculturality.

Although the approach comes across as sincerely benevolent, the risk inherent in contextualizing interculturality within a linear trajectory is that of barring the Other from being a historical subject by splitting time into binaries: the presence of the Other is tied to an external phenomenon that rejects the possibility of full national validation - being an 'us' rather than a 'them' - since the Other is exclusively part of 'these times' and is absent in 'those times' (Spivak 1990). The decisive subtext of such a statement is that the arrival of Others and the cultural traditions that they carry with them is not only the source of multiculturalism but also - although this runs contrary to multiculturalism's aims - of the tacit reproduction of a discursive divergence between different expressions of culture. As it is phrased in the excerpt, 'separate ethnic and cultural backgrounds' are from the outset considered to be manifestations of difference; relying on the myth of the nation as having been once upon a time homogenous and pure (Bhabha 1994). In other words, the reasons for teachers to be intercultural were non-existent yesterday; this is a necessity of today for the sake of tomorrow.

\section{Attempts at Translation: Efforts Without Guarantees}

What becomes apparent in the above is that interculturality treats multiculturalism as part of its pretext, as what needs to have happened before interculturality can take place. In short, the need for interculturality is not applicable to every encounter; it demands border crossing, beginning with the arrival of 'new peoples'. That is to say, it starts with immigration and the consequent presence of radical otherness. Since the moment of multicultural transformation, according to the literature, has already passed, interculturality points to where 'we' need to arrive as a group (learning to live with 
difference) and what 'we' need to acquire as individuals (learning to become intercultural) in a constantly changing society. And with new compositions, come new challenges:

[Interculturality] is a process by which two individuals who do not belong to the same culture 'try' to exchange a set of ideas, feelings, symbols... meanings. Since they do not belong to the same culture, it implies that they do not share the same assumptions, beliefs, values or... same ways of thinking, feeling, and behaving. This phenomenon makes the communication process much more difficult and challenging than we think (Kohls \& Knight 1994: 59).

While this quotation partly echoes what has already been deduced above in stressing that interculturality can take place only between two distinctive parties separated by cultural belonging, this passage goes into greater depth in its framing of 'culture' as a diversifying factor which influences ways of thinking, feeling and behaving to such a degree that interpretation of them is a highly daunting task: our differences are also our limitations. As signalled by the insertion of 'try', interchange across cultural borders always entails a restriction on what can be translated from one culture to the other. Having said that, the conceivable obstacles are not intended to function as deterrents but rather as arguments in support of the necessity of interculturality. As such, by acknowledging these impediments to communication interculturality marks the possibility of exchanging 'assumptions, beliefs, values' as well as ways of 'thinking, feeling, and behaving' in relation to the radically different Other. Presented with a convoluted double bind, the implied reader of the text is urged to try to exchange cultures with an Other whose ways of thinking, behaving and feeling are so distinctively different that the communicative act in itself is at risk: culture cannot be exchanged, culture must be exchanged.

Sympathetic as I am to the work of raising consciousness of the limitations of translation, on condition that interculturality is acknowledged as a diverse, ambiguous, lived process rather than a reified concept, yet the quotation above - as well as the text at large - leaves me with an abiding feeling of unease. Firstly, it overlooks the downside to the desire for dialogue. In all of these texts, it is made abundantly clear that conversation, or intercultural dialogue, is considered indispensable to the good of the pedagogical encounter. For instance, interculturality 'is based upon openness and understanding', asserts one of the books, 'and shall lead to a good two-way communication between individuals of different ethnic or cultural backgrounds' (Borgström 2004: 33). Without wishing to reject the ideal of a politically informed and genuine dialogic encounter, it should be noted that nowhere does this book address a scenario in which the idea of dialogic encounter fails to hold a compellingly positive meaning for the Other. That possibility is acknowledged, however, by Alison Jones (1999) who warns against the imperialistic assumptions often underlying calls for dialogue, as they are rooted in a request for action emanating from a dominant group which makes a demand of the Other to respond, interact and follow suit. Listening, translating or crossing into the realms of the Other - prerequisites for dialogue and consequently for intercultural pedagogy - potentially have more troubling connotations for members of unequally positioned groups (Aman 2014c).

Secondly, this interpretation of interculturality also leaves untouched the related question of the language in which the Other responds when in contact with the self. The transfer of 'ideas, feeling, symbols' is conditional, permanently accompanied by hesitation; yet the central issue that the inability to fully translate may be related to the lack of a shared language is absent from these discussions. As far as language is concerned, the Other is always accessible. But absence supplies its own underlying 
meaning; it speaks through its exclusion from presence (Derrida 1998b). The scant attention directed towards language, as a fundamental element in communication with the Other, in the literature on interculturality suggests shared languages or, at the very least, the potential to communicate in similar vernaculars. In turn, the absence of translation from the communicative act privileges the presence of the written languages that have produced the texts under scrutiny.

Language, then, is seemingly the basis of the affiliation that the text holds out to a fit reader: it is the choice of language that ensures that the words reach their proper addressee, the invoked subject of interculturality. A predicament that faces any teaching text is that of fostering inclusion at the price of a concomitant exclusion, and the reasons for the writers' conscious or unconscious decision to give way to other aspects of interculturality can be roughly divided into two types: internal and external. Beginning with the latter, one possible scenario is that the literature was simply produced with the assumption that the implied reader already has the linguistic tools to reach a sufficient portion of the world's population through the growing power of English as a global lingua franca. As for the former, a singular focus on the implications for interculturality within the national context assumes that the migrant who has settled within the nation will eventually have to learn a dominant local tongue. The reduced role of language, then, suggests, albeit implicitly, that the responsibility for communication lies not with the subject the literature speaks to ('us') but with those it speaks about ('them') - those who have come from afar to enter our classrooms (Aman 2012). In unarticulated fashion, the Other is consequently subject to the requirement to learn the language of interculturality, and the double bind presents itself in the simultaneous construction of two conflicting subject positions: on the one hand, interculturality is dependent on otherness through the establishment of absolute alterity; on the other hand, a prerequisite for being addressed by interculturality as Other is to resemble, however minimally, the self by communicating in 'our' language - it demands a certain prior degree of assimilation, since the sign system in use belongs to the 'we'.

\section{Global Westerners, Local Others}

To a large extent the texts under scrutiny are preoccupied with the contexts in which they were produced, with how interculturality might contribute to renewed social cohesion within the sphere of the nation. Nevertheless, the literature analysed here also includes more outward-looking cases, that is to say teaching examples of encounters on foreign soil between individuals with whom the texts identify and the local Other. Their purpose is two-fold: firstly, the reader is encouraged to visit other parts of the world, to encounter and experience other cultures since, as one of the texts argues, 'it seems very unlikely that one through literature studies, courses or conversations with experts can obtain any deeper insights about a culture' (Stier 2009: 140); or as formulated in another text, 'intercultural communication presupposes experience of intercultural contacts and meetings. These meetings enable the individual to understand the culture of the Other [...] but this is not automatic and painless since it is not possible to only theoretically, i.e. cognitively, learn how to become aware of one's own cultural beliefs and limitations' (Lahdenperhä 2004: 19).

With previous references to the Other having been restricted to the newly arrived migrant, the contrast is profound: the presence of the Other here marks the need, 'our' requirement, to accommodate in becoming intercultural but, at the same time, it is exposure to otherness there, the geopolitical roots of the Other, that helps 'us' to 
become intercultural. Given that the self in interculturality has to be, in theory, generalizable the double bind is encountered in the construction of a position which on a rhetorical level can be occupied by anybody with the proper knowledge; at the same time, this knowledge is not attainable through literature but can only be gained by travelling, by exposure to otherness in another context. Consequently, interculturality is not for anybody and everybody; it speaks from the outset to an already privileged group (Aman 2013, 2014b).

Secondly, in depicting the process of transforming oneself into an alien element in a presumably unaccustomed environment, the authors attempt to provide pedagogical samples with a moral message about the risk both of jumping to conclusions and of reading otherness through an ethnocentric lens. In Developing Intercultural Awareness, the examples stretch from religious conflicts in a Middle Eastern classroom, hierarchies in family life in Thailand and gender roles in South Korea to perceptions of time in Portugal and the concept of respect in Germany. The broad spectrum presented here suggests not only the variety of aspects of otherness encapsulated by interculturality; it also says something about the amount of training required to be properly attuned to this way of thinking. The ability to translate across cultures and between differences is indeed a skill as important as it is demanding to master. Yet it is specifically the wide-ranging skill set of interculturality that echoes its previous association with privilege: the intercultural subject is elite precisely because they can communicate with a diverse set of people (Ahmed 2007).

Shifting the emphasis now from the texts' implied reader to those who are spoken about: the aim of the example from Germany is to illustrate different understandings of the concept of respect, and the focus is on a lecturer from the United States invited to speak to a large audience. Assuming a somewhat casual posture with one hand in his pocket, his attempts to incorporate humorous anecdotes into the address are met with strained silence. 'Other audiences have appreciated his humour', the text goes on to explain, 'and it has served to relax them and gain their attention before he continued on in a more serious vein' (Kohls \& Knight 1994: 94). In their analysis of the event, the authors explain that in Germany informality is out of place in a formal setting and comes across as disrespectful. The same goes for jokes or humour, the authors inform their reader, which should be reserved for less strict occasions, and by way of conclusion they insert a reminder that humour does not always translate across cultures. 'German speakers build their bonds on greater respect', the text continues, 'rather than casualness' (Kohls \& Knight 1994: 95).

In all fairness, these insights into what is considered right and wrong, appropriate and inappropriate may turn out to be truly helpful for any given reader of the book. Having said that, there is no getting away from the fact that in place of specificity the authors homogenize national characteristics allied to stereotypes (the serious and humourless German; the Portuguese's casual relationship to time). Rather than letting these pass as harmless descriptions for the sake of pedagogy, it is important to recognize that the choice of samples reflects, unknowingly or even knowingly, phenomena that are at odds with the assumed normality of the implied reader; and also, that the choice of samples reveals the authors' position in relation to the geo-political context they describe (Aman 2014a). When the examples picked to describe a European context revolve around issues of a more shallow nature, this at the same time suggests a sense of proximity since differences are so minor that it is only with recourse to sense of humour that duality can take shape. By contrast, outside the realm of Europe differences manifest themselves in a more profound way in the literature. Under the header 'Cultural Differences in Social Roles', Developing Intercultural Awareness 
gives an account from an American couple who have gone to Korea for teaching assignments. In a letter, the wife gives information about their experiences as new arrivals in the country and their attempts to get acquainted with their new co-workers:

During this time my husband's co-teachers in his department were regularly inviting him to go out to dinner at one restaurant or another, and I accompanied him to them. I was always the only woman present, and though we repeatedly asked them to bring their wives along, I remained the only woman. After a number of such occasions, we became the object of their jokes. My husband was henpecked because I had made him stop drinking and wouldn't let him go out during the week drinking with the men. I was also the domineering American wife who controlled her husband and refused to stay at home. We became quite uncomfortable, and when the teachers had apparently had their fun, their invitations suddenly ceased. Now, our only Korean social companions are our language tutors - a Korean couple our age, well educated. He had been to the United States. They are extremely unusual as they enjoy going to dinner, the movies, and parties as a couple (Kohls \& Knight 1994: 103).

This passage draws attention to possible scenarios in which interculturality is inadequate, occasions when histories, value systems and codes inevitably collide. Nevertheless, it is of particular importance to point out that the story cited is written from the perspective and assumptions of the West. Alongside their homogenization of Korean society as such, the couple ascribe to themselves the position of modern ideals caught in the context of traditional and backward values, a picture affirmed by the introduction of the Korean couple into the story who, in a development essentially linked to the attainment of an American university diploma, have embraced a Western perspective on socializing. In this production of binary oppositions that separate the modern subject from a primordially paternalistic context, the Korean couple are turned into a metaphor for progress, the potential to modernize. Without ignoring the feelings of unease experienced by the American couple, it should be noted that the text unconsciously ignores important cultural and class differences while construing the couple as both socially and culturally superior to Koreans. They are unselfconscious about their own relationship to the oppressive power structures that operate between the West and non-Western countries (Spivak 1985).

Taken as a whole, neither in the passages cited above nor in those previously enumerated are anything other than Western eyes accounted for; never allowed an enunciative position, there are no records that the subject-conscious Other ever exists. Rather than invoking - to make use of the most recent example - any of the locals (for instance, the co-workers), or more importantly the perspective of the Korean women whose subordinate roles the narrator laments, the Others remain quiet, reduced to human scenery, and the texts in a similar manner fail to specify the limits of their own field of enunciation, their own restricted ability to read and understand otherness. In this sense, interculturality risks becoming a strictly Western affair, an ongoing dialogue above the head of the Other, or as it is pithily put by Trinh Minh-ha (1989: 67): "A conversation of "us" with "us" about "them" is a conversation in which "them" is silenced. "Them" always stands on the other side of the hill, naked and speechless, barely present in absence.'

\section{Conclusion}

Although several academic commentators have made advances beyond the taxonomic assumptions of the nation-state as a unified field of analysis for intercultural education (Arnove 2007; Cowen 2009; Gundara \& Portera 2008), others have pointed out that the drawing of national borders remains a potent symbol of cultural unity within interculturality (Bash \& Gundara 2012; Gorski 2008). A similar pattern has been 
detected in this essay. The points made above do not in any way aim to discredit the authors' position that interculturality is needed in contemporary Western societies. Some versions of this approach are undoubtedly indispensable and despite the problems described throughout this essay, certain merits of interculturality as displayed in the educational texts under scrutiny cannot simply be brushed aside. Nevertheless, what I have shown here is that for all their benevolent intentions, the texts seem to be reproducing the lamentable phenomenon that Spivak $(2012,147)$ labels 'easy traffic in ethnicity [...] characteristic of the dream of interculturalism.' general thrust of the argument developed here has been that in its current articulation interculturality remains caught up in the construction of sameness and otherness along arbitrary national borders and does little to cater for multiple, as opposed to national, or other unified, identities (Lentin 2005). This tendency, then, in the literature to pigeonhole people by culture often fails to acknowledge the sheer diversity within nations, not to mention the utter diversity to be found inside a single human - again, interculturality before interculturality. As a consequence, the double bind returns to present itself: at the same time as the act of crossing cultural borders is valorized and encouraged in the name of solidarity and dialogue, borders are instituted in the process of relating to a perceived Other in opposition to a same. Thus, in attempting to bridge cultural differences, interculturality at the same time, in contradictory fashion, risks sustaining the unity of national identities.

To define the subject along national lines, however, is not necessarily a pathology but a grounding error that enables us to make sense of our lives, an inevitable consequence of our need to process the world and communicate with one another by means of labels and organizing categories (Spivak 1992). But as difficult as it may be to avoid, allowing imprecise notions of cultural and national identity to lurk in interculturality not only denies interculturality but continues to produce a double bind: the construction and maintenance of cultural identity involves the establishment of a competing alter ego, so that interculturality risks preserving that which is deemed to be Other as other by transforming it into a representative of that very otherness. Against this backdrop, it seems that a task that still lies ahead for all of us, then, is to develop a more dynamic understanding of interculturality that takes into account the existence of hybrid cultures whose paradoxical makeup cuts across the binaries of national belonging; an approach that makes it possible for interculturality to be reconciled with interculturality.

\section{Acknowledgments}

I would like to express my gratitude to Andreas Fejes, Stefan Jonsson and the journal's reviewers for their generous assistance. 


\section{References}

Ahmed, S. 2007. The language of diversity, Ethnic and Racial Studies 30, no. 2: 235-256.

Aman, R. 2012. The EU and the Recycling of Colonialism: The Formation of Europeans Through Intercultural Dialogue. Educational Philosophy and Theory. 44, no. 9: 1010-23.

Aman, R. 2013. Bridging the Gap to Those Who Lack: Intercultural Education in the Light of Modernity and the Shadow of Coloniality. Pedagogy, Culture \& Society 21, no. 2: 279-97.

Aman, R. 2014a. Impossible Interculturality?: Education and the Colonial Difference in a Multicultural World. Linköping: Linköping University Press.

Aman, R. 2014b. In the Name of Interculturality: On Colonial Legacies in Intercultural Education. British Educational Research Journal: 115.10.1002/berj.3153

Aman, R. 2014c. Why Interculturalidad is not Interculturality: Colonial Remains and Paradoxes in Translation between Supranational Bodies and Indigenous Social Movements. Cultural Studies: 1-24.10.1080/09502386.2014.899379

Anderson, B. 1982. Imagined Communities. London: Verso.

Appiah, K. A. 2006. Cosmopolitanism: ethics in a world of strangers. New York: W.W. Norton.

Arnove, R. 2007. Introduction: Reframing comparative education. In Comparative education: The dialectic of the global and the local, eds. R. Arnove and C. Torres. Lanham, ML: Rowman \& Littlefield Publishers.

Bash, L. \& Gundara, J. 2012. Contesting borders: a challenge to some paradigmatic assumptions of intercultural and comparative education. Intercultural Education, 23, no. 5: 383-395.

Bhabha, H. K. 1994. The Location of Culture. London: Routledge.

Borgström, M. 2004. Lärarens interkulturella kompetens i undervisningen. In Interkulturell pedagogik $i$ teori och praktik ed. P. Lahdenperä, 33-56. Lund: Studentlitteratur.

Chaudhuri, U. 2002. Beyond a 'Taxonomic Theater': Interculturalism after Postcolonialism and Globalization, The Drama Review, 32, no: 33-47.

Chow, R. 1998. Ethics after idealism: theory, culture, ethnicity, reading. Bloomington: Indiana University Press.

Coulby, D. 2006. Intercultural education: theory and practice, Intercultural Education 17, no. 3: 245-257.

Cowen, R. 2009. On history and on the creation of comparative education. In International handbook of comparative education, ed. R. Cowen and A. Kazamias. Dordrecht: Springer.

Damrosch, D. 2003. What is world literature? Princeton, NJ: Princeton University Press.

Derrida, J. 1998a. Monolingualism of the other, or, the prosthesis of origin. Stanford: Calif.: Stanford University Press.

Derrida, J. 1998b. Of Grammatology. Baltimore: Johns Hopkins University Press.

Dewey, P. 2008. Transnational Cultural Policymaking in the European Union. The Journal of Arts Managment, Law, and Society 38, no. 2: 99-118.

Ghosh, A. 1988. The Shadow Lines. London: Bloomsbury. 
Gorski, P. 2008. Good intentions are not enough: a decolonizing intercultural education, Intercultural Education 19, no. 6: 515-525.

Gundara, J. 2000. Interculturalism, Education and Inclusion. London: Paul Chapman Publishing.

Gundara, J. \& Portera, A. (2008) Theoretical Reflections on Intercultural Education, Intercultural Education 19, no. 6: 463-468.

Hughes, C. 2009. International education and the International Baccalaureate Diploma Programme. Journal of Research in International Education 8, no. 2: 123-41.

Jones, A. 1999. The limits of Cross-Cultural Dialogue: Pedagogy, Desire and Absolution in the Classroom. Educational Theory 49, no. 3: 299-316.

Jonsson, S. 1993. De andra: amerikanska kulturkrig och europeisk rasism. Stockholm: Norstedt.

Khatibi, A. 1993. A Colonial Labyrinth. Yale French Studies 2, no. 83: 5-11.

Kohls, L. R. and Knight, J. M. 1994. Developing intercultural awareness: a crosscultural training handbook (2. ed.). Yarmouth, Maine: Intercultural Press.

Kymlicka, W. 2003. Multicultural states and Intercultural citizens. Theory and reserach in Education 1: 147-169.

Lahdenperä, P. 2004. Interkulturell pedagogik i teori och praktik. Lund: Studentlitteratur.

Leeman, Y. 2003. School Leadership for Intercultural Education. Intercultural Education 14, no. 1: 31-45.

Lentin, A. 2005. Replacing 'Race': Historicising the 'culture' in multiculturalism. Patterns of Prejudice 39, no. 4: 379-96.

Minh-ha, T T. 1989. Woman, native, other: writing postcoloniality and feminism. Bloomington: Indiana University Press.

Meer, N. and Modood, T. 2011. How does interculturalism contrast with multiculturalism?. Journal of Intercultural Studies 33, no. 2: 175-96.

McDonald, P. 2011. Thinking interculturally. Interventions 13, no. 3: 367-85.

Murphy, M. 2005. Multiculturalism. London: Routledge.

Rushdie, S. 1991. Imaginary Homelands. London: Granta.

Said, E. 1994. Culture \& Imperialism. London: Vintage.

Smith, M., \& Guarnizo, L. eds. 1998. Transnationalism from Below. New Brunswick, NJ: Transaction Publishers.

Spivak, G. C. 1985. Three Women's Texts and a Critique of Imperialism. Critical Inquiry 12, no. 1: 243-61.

Spivak, G. C. 1990. The post-colonial critic: interviews, strategies, dialogues. New York: Routledge.

Spivak, G. C. 1992. Acting Bits/Identity Talk. Critical Inquiry 18, no. 4: 770-803.

Spivak, G. C. 2012. An aesthetic education in the era of globalization. Cambridge, MA: Harvard University Press.

Stier, J. 2009. Kulturmöten: en introduktion till interkulturella studier. Lund: Studentlitteratur.

UNESCO. 2006. Guidelines on Intercultural Education. Paris: UNESCO.

Weaver, M. (2010) Angela Merkel: German multiculturalism has utterly failed, The Guardian, 17 October.

White, H. 1972. The Forms of Wildness: Archaeology of an Idea. In The wild man within, eds. E. Dudley and M. Novak, 3-38. Pittsburgh: University of Pittsburgh Press. 
${ }^{\mathrm{i}}$ This quotation is mentioned by Gayatri Chakravorty Spivak (1990, p. 60) in an interview with Sneja Gunew in which she comments on identity politics, representation and the dangers of homogenizing when discussing multiculturalism, stating that 'Proust in $A$ la recherche, when someone is criticizing Françoise's French, writes, "What is French but bad Latin?" So from that point of view, one can't distinguish, you can't say that this is a French position or a Roman position.'

ii The following texts are included in the analysis: Developing Intercultural Awareness: A Cross-Cultural Training Handbook, Cultural Encounters: An Introduction to Intercultural Studies; Cultural Encounters: An Introduction to Intercultural Studies (title in Swedish: Kulturmöten: En introduktion till interkulturella studier); Intercultural Pedagogy in Theory and Practice (title in Swedish: Interkulturell pedagogik i teori och praktik). It is necessary to add that I do not regard the material as homogenous by any means. The mere fact that the texts under scrutiny are published in the US and Sweden raises questions about the codification of interculturality depending on context. Although it is not ignored, it is not the main aim of this essay to trace contradictions and differences in interpretations of interculturality. No matter the context, however, an indispensible ingredient of interculturality is the construction of sameness and otherness. Thus, the critical analysis performed in this essay operates on a general level. iii My italics. 